International Journal of Agriculture, Environment and Bioresearch

Vol. 06, No. 05; 2021

ISSN: $2456-8643$

\title{
TYPOLOGY AND SOCIO-ECONOMIC IMPACTS OF HYDRO-AGRICULTURAL DEVELOPMENTS IN THE MUNICIPALITY OF ADJA-OUERE SOUTH EAST OF BENIN
}

\author{
ZANNOU Sande ${ }^{1}$ and DOSSOU GUEDEGBE Odile ${ }^{2}$ \\ Laboratory of Territorial Planning, Environment and Sustainable Development (LATEDD) / University of Abomey- \\ Calavi, Benin \\ https://doi.org/10.35410/IJAEB.2021.5662
}

\begin{abstract}
Agriculture, the basis of the Beninese economy, mobilizes several producers in Adja-Ouèrè to develop different techniques to make their production profitable. This research analyzed the socio-economic impacts of hydro-agricultural developments in the Commune of Adja-Ouèrè. To achieve this objective, data was collected through individual interviews with 201 households and interviews with 25 resource persons. These data were processed by calculating the response frequencies of the respondents, which were translated into tables and graphs using the Excel 2013 spreadsheet. The geographical coordinates of the hydro-agricultural facilities were used to produce the distribution map of the structures with the Arc gis 10.5 software.

The results showed that there are 43 hydro-agricultural development sites distributed in the 6 districts of the commune of Adja-Ouèrè organized into 5 categories: development by dykes and dikes $(16.27 \%)$, development by drilling (2.33\%), development by sprinkling (53.49\%), by mounds and ridges $(23.26 \%)$, and development by watering $(4.65 \%)$ The main crops grown in managed areas are vegetables (40\% of sites), cereal crops (32\% of sites), tubers $(14.29 \%)$ and legumes and other fruit trees (13.71\%) of managed sites overall. The benefit varies according to the type of management, crop and area covered. The socio-economic importance of these developments is mainly related to the income that producers receive, which varies according to the type of development carried out and the area covered. Indeed, the borehole system brings in an average of 2,202,000 FCFA per hectare for the producer, compared to 850,000 FCFA for the modern sprinkler system, 705,000 FCFA for the traditional sprinkler system, and 855,000 FCFA for the dyke and bund systems. However, the mound and sprinkler systems are less profitable, yielding 435,000 FCFA and 552,000 FCFA respectively. In spite of these advantages, producers encounter various difficulties in carrying out hydro-agricultural development, notably the lack of financial means, the overabundance of rainfall that ravages agricultural products and dikes, and land conflicts.
\end{abstract}

Keywords: Adja-Ouere, hydro-agricultural development, socio-economic impacts, constraints.

\section{INTRODUCTION}

Agriculture is an important component of the economies of developing countries. It is "the heart of economic development in all of these countries" (WARDA, 2005, p. 35). In Africa, it contributes nearly "50\% to the Gross Domestic Product (GDP) and employs nearly $80 \%$ of the 
Vol. 06, No. 05; 2021

ISSN: $2456-8643$

working population" (F. Houintchekpo, 2019, p.12).

In Benin, this sector is also the main source of national economic wealth creation. "More than $60 \%$ of active men and $35.9 \%$ of really employed women work in an agricultural profession" (INSAE, 2013, p.2). Moreover, "its contribution to GDP is on average around 33.3\% over the period 1995-2005 and 31.5\% over the period 2005-2008 with a contribution of $88 \%$ to export earnings" (S. Agbazahou, 2013, p.75). "Plant production is predominant and intervenes on average for $24.1 \%$ while animal and fishery production contributed on average respectively for 5.9\% and 4.2\%" (FAO and Songhaï, 2010, p.5) .

Despite this contribution to the national economy, Beninese agriculture is dependent on the climate and encounters enormous difficulties linked to "the rural exodus, the use of archaic tools, land conflicts and the degradation of land or water. surface area is available throughout the country in more than twenty sub-watersheds and four large hydrographic complexes (MonoCouffo, Ouémé-Yénawa, Volta and Niger) for hydro-agricultural developments (DGEau, 2008, p. 12)". "The country is also showing strong demographic growth of around $3.25 \%$ per year and a particularly high population density in the southern regions where $44 \%$ of the population is concentrated and occupies 10\% of arable land" ( JG Agbodjogbé, 2008, p.85).

This demographic surge contributes to the degradation of agricultural ecosystems due to "extensive cultivation and a reduction in the duration of fallows" (M. Lanokou et al., 2013, p.326). Thus, "the number of farms in existence today is estimated at around 550,000, spread over eight agro-ecological zones. They are mostly made up of small family farms, oriented towards mixed farming, often associated with small livestock. The average area of peasant farms is estimated at $1.7 \mathrm{ha}$, on which an average of 7 people live. About $34 \%$ of farms cover less than one hectare. Only $5 \%$ of farms in the south and $20 \%$ in the north of Benin cover more than 5 ha. Of the 11 million ha of gross area available, just under $60 \%$ is suitable for agriculture "(PNIA / ECOWAP / CAADP, 2008, p.18).

These findings are common to all the municipalities of the country, particularly the municipalities in the south where population growth and urban expansion encroach on agricultural land, as is the case in the municipality of Adja-Ouèrè where the solution to meet the challenge of food security is to carry out intensive agricultural production in areas developed as dykes and ponds using surface water for irrigation. This is why "several projects or programs have emerged in the agricultural sector for hydro-agricultural developments" (C. Hounketin, 2003, p.85). The development of the lowlands is placed in the foreground of the section and particularly affects the municipality of Adja-Ouèrè. However, despite these efforts made in this municipality, it is clear that "the players have not yet managed to exploit the lowlands to optimize their profit margin" (Y. F. Ehoulo, 2008, p.28). The concern of this research is to assess the socio-economic impact of hydro-agricultural developments in the municipality of AdjaOuèrè, taking into account the constraints that inhibit profitable exploitation of land in the research sector.

\section{RESEARCH ENVIRONMENT}

Covering an area of $550 \mathrm{~km} 2$, the municipality of Adja-Ouèrè is located in the South-East of Benin between $6^{\circ} 36^{\prime} 19$ " and $7^{\circ} 06^{\prime} 19 "$ from the North attitude and between $2^{\circ} 30^{\prime} 15$ " and $3^{\circ} 00$ 'East longitude (figure 1). 


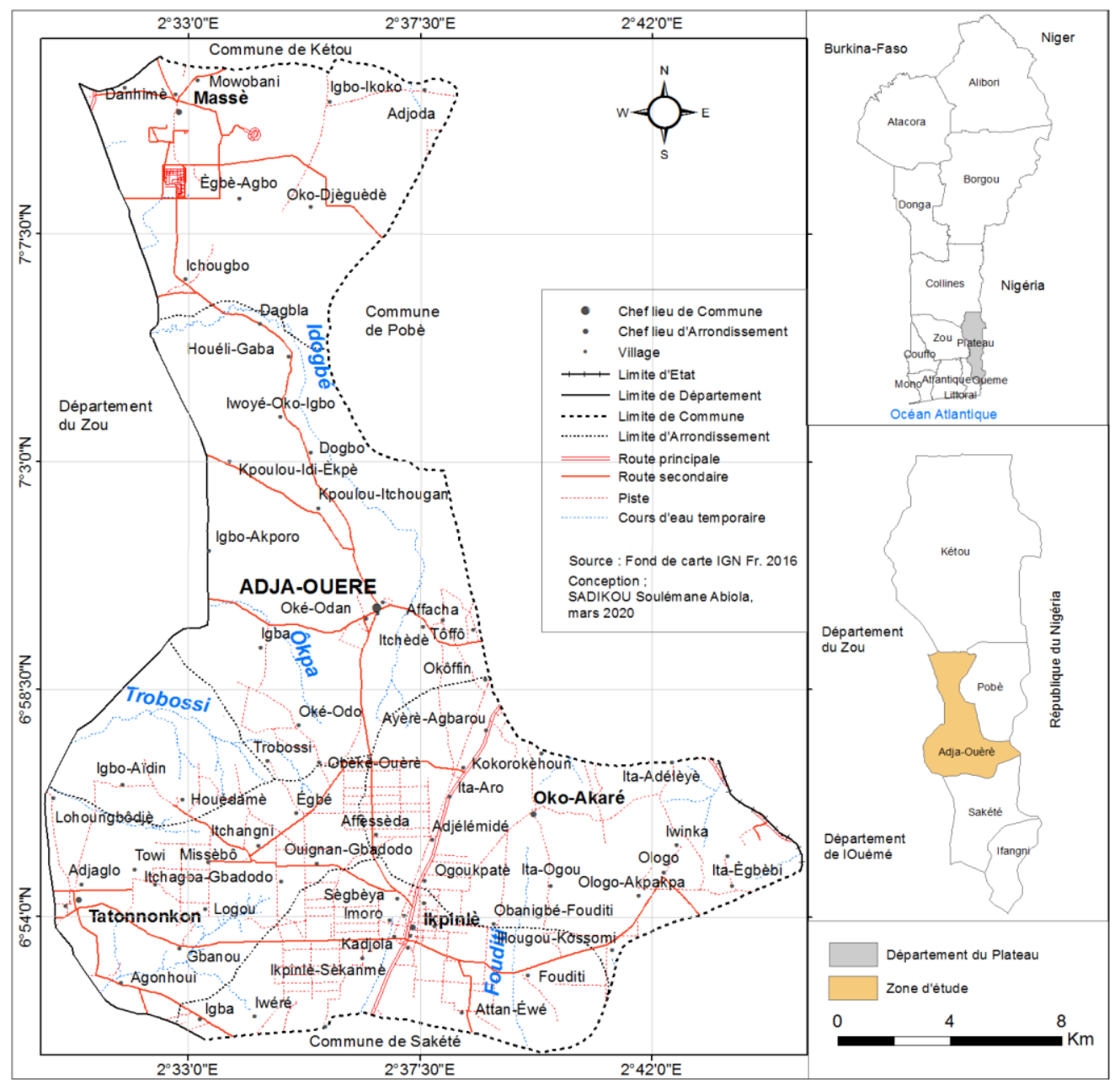

Figure 1: Geographical location of the municipality of Adja-Ouèrè

The town enjoys a subequatorial type climate with two (02) alternating dry seasons. Precipitation reaches 1,100 to 1,200 mm per year (Météo-Bénin, 2019, p.51). This climate is an asset for agriculture and favors hydro-agricultural development. There is also a large workforce for agricultural production in the municipality (INSAE, 2013, p.8).

\section{MATERIALS AND METHODS}

\subsection{Typology of data collected in the field}

The data collected in the field are: (i) the geographical coordinates of the hydro-agricultural development sites; (ii) Types of hydro-agricultural developments by district; (iii) modes of access to land; (iv) products cultivated by management; (v) the selling price of the products and the profits made; (vi) the advantages of developed sites; (vii) the quality of the workforce, (viii) the involvement or not of the town hall; and (ix) constraints of hydro-agricultural development. 
Vol. 06, No. 05; 2021

ISSN: $2456-8643$

\subsection{Sampling and data collection techniques in the field}

The surveys were carried out in the six (06) districts of the municipality of Adja-Ouèrè, but thirty-seven (37) villages out of the seventy-two (72) in the municipality were visited. These villages were selected taking into account the size of agricultural households and the presence of hydro-agricultural development sites. The choice of household heads (i) was made on the basis of their age (25 years) (ii), the provision of irrigation schemes (iii) and the year of residence in the municipality (10 years ) (iv). These criteria made it possible to question two hundred and one (201) (43 peasants with irrigation facilities and 158 peasants without these facilities) households distributed in the six (06) districts. This sample was obtained with the formula of C. Morgan (2011): $\mathrm{T}=\mathrm{M} \times \mathrm{F}$ with $\mathrm{T}=$ the size of the sample; $\mathrm{M}$ : total number of households (4025); $\mathrm{F}$ : the sampling rate set arbitrarily at $5 \%$

$\mathrm{T}=4025 \times 5 / 100=201.25$ or 201 households. In addition to these respondents, 3 ATDA agents, 1 Head of the State and Environmental Affairs Department, 6 District Heads and 15 Village Chiefs were interviewed.

The surveys were conducted from April to September 2020 in households or in the fields depending on the place where the respondent was found by individual interviews using a questionnaire established for this purpose. Interviews were conducted with resource persons using an interview guide. Direct observations made it possible to note the types of works and the speculations produced by the peasants.

\subsection{Data processing techniques collected}

The investigation sheets were checked and analyzed. The number of responses by type of question was expressed by the statistical protocol by calculating the frequencies: $\mathrm{P}=\mathrm{n} / \mathrm{N} \times 100$ with $\mathrm{n}$ : the number of households which gave positive responses and $\mathrm{N}$ : the total number of respondents. This frequency was applied to all data collected. The different frequencies determined were transformed into tables and graphs on the Excel 2013 spreadsheet. The geographical coordinates made it possible to spatialize the hydro-agricultural development sites in the town. This analysis made it possible to cross-reference the number of hydro-agricultural development works by type and by district. These cartographic operations were carried out using the Arc gis 10.5 software. The economic impacts of hydro-agricultural developments were assessed on the basis of the expenses incurred by producer for a season by subtracting the selling prices of the harvested products.

\section{RESULTS}

\section{1 . Typology of hydro-agricultural developments in the Municipality of Adja-Ouèrè}

Different types of hydro-agricultural development are carried out in the Municipality. The investigations made it possible to identify 43 sites developed for irrigated agriculture and divided into 5 categories. Figure 2 shows the hydro-agricultural sites developed by type in the Municipality. 


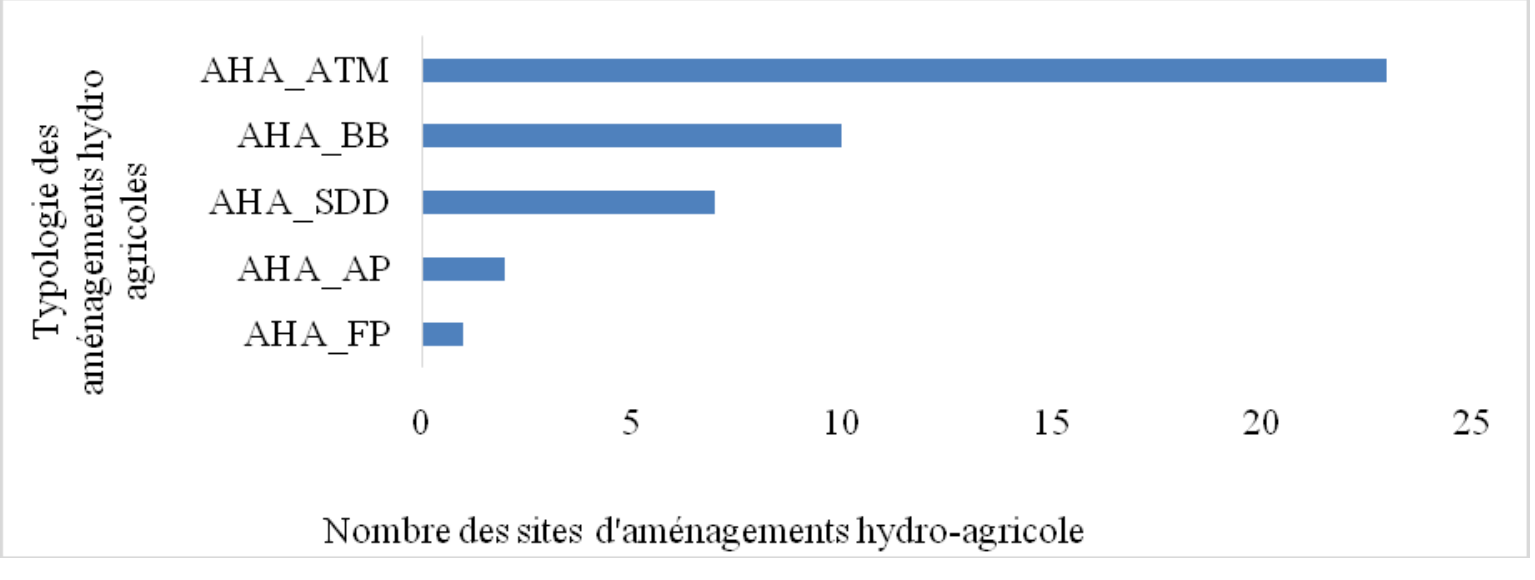

Figure 2: Typology of irrigation schemes in the municipality of Adja-Ouèrè

Source: Field surveys, April to September 2020

AHA-FP: Hydro-Agricultural Development by Pumping or Drilling; AHA-AP: HydroAgricultural Development by Watering Plants; AHA-SDD: Hydro-Agricultural Development by System of Dikes and Bunds; AHA-BB: Hydro-Agricultural Development by Billonnage and Raising; AHA-ATM: Hydro-Agricultural Development by Traditional and Modern Sprinkling

\subsection{1- Hydro-agricultural development by pumping or drilling}

Hydro-agricultural development by pumping consists of feeding crops from an underground and / or surface water source. It is an installed piping system that carries water from the source to the field in all seasons. The hydro-agricultural development by pumping or drilling represents only $2.32 \%$ of the hydro-agricultural developments made in the municipality. Photo 1 shows the device that operates the pumping management system.

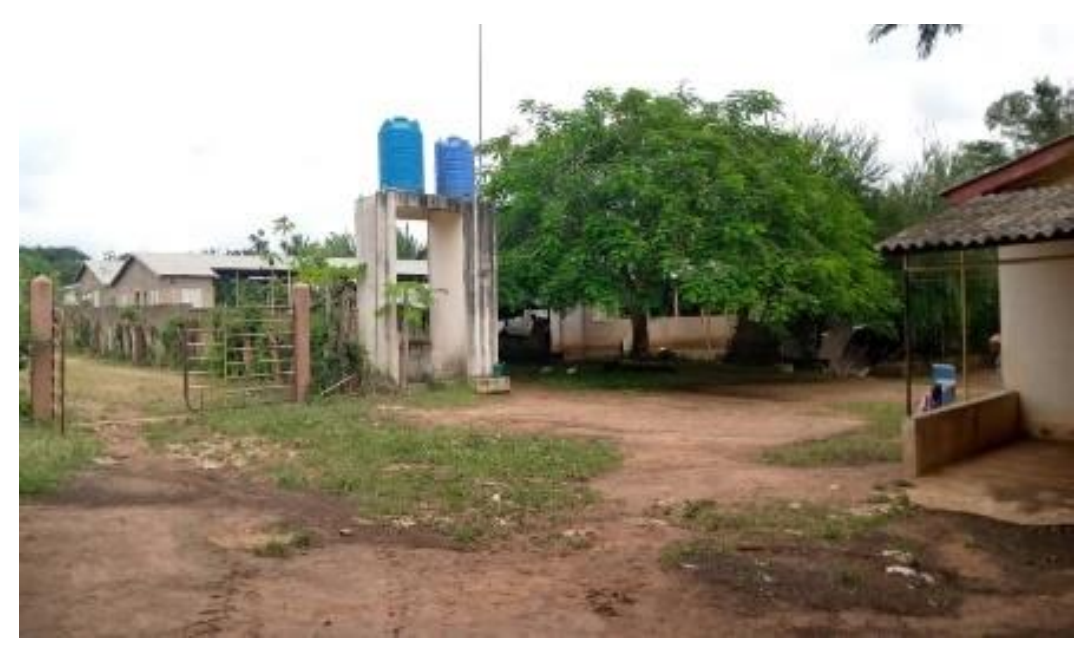

Photo 1: Borehole installed in a farm in Ita-Bolarinwa

Shooting: Zannou, September 2020. 
In photo 1 it can be observed a borehole to which pipes are connected to water the fields in. It should be noted that the Episcopal farm in Ita-Bolarinwa is the only Episcopal farm that is set up in this way in the entire municipality of Adja-Ouère.

\subsection{2- Hydro-agricultural development by sprinkling}

Arrangement by sprinkling consists of draining or supplying water from a permanent source (natural watercourse, water retention) for modern or traditional sprinkling. From these sources, the peasants dig trenches leading water over a distance of 100 to 250 meters to irrigate two or three fields in the traditional way using a single pipe in record time (one hour). . This type of development is the most common in the municipality with 23 developed sites, ie 53.49\%. Photo 2 shows a traditional sprinkling in Ségbeya.

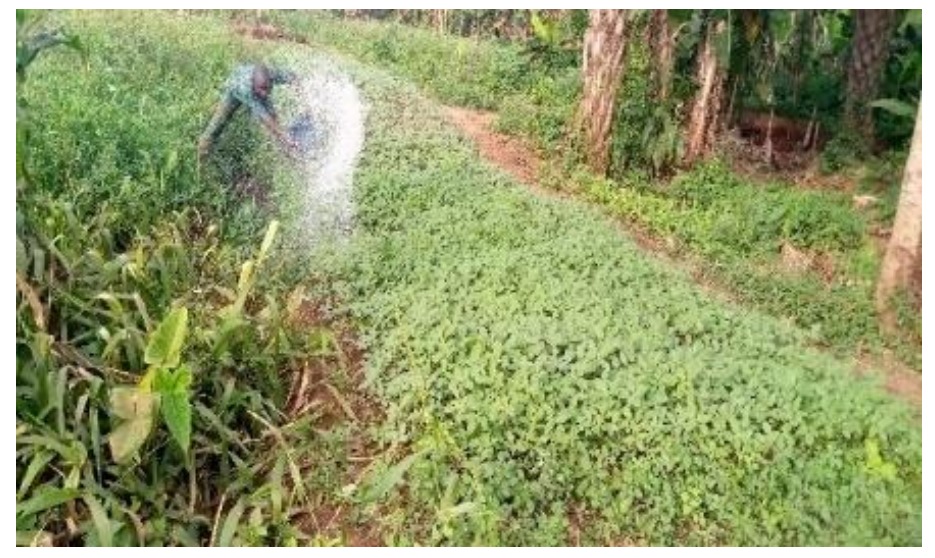

Photo 2: Traditional sprinkling of vegetables in Ségbeya

Shooting: Zannou, September 2020

Photo 1 shows that in the semi season, the edges of these canals, considered as ridges, are occupied by off-season crops. This technique allows for agricultural production in any season thanks to the availability of water. It is by the way

\subsection{3- Hydro-agricultural development by dyke and bund}

This type of development consists of digging sloping flues, to bring water to a field that is lacking or to evacuate in the event of excess (flooding), in the event of an abundance of rain. This is a flat locker arrangement, fed by an irrigation canal connected to a natural or created water point. This development is suitable for areas with significant surface water resources (stretches and streams, ponds, recovery cisterns, etc.) and is more practiced in depressions, or in marshes and swamps (photo 3). 


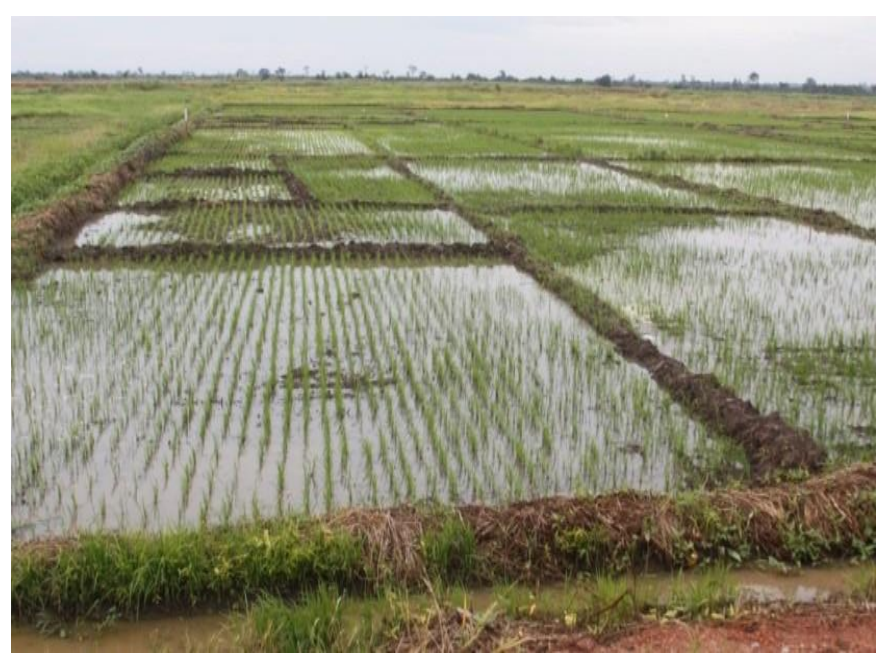

Photo 3: Hydro-agricultural development by dikes and bund

Shooting: Zannou, September 2020

Through photo 3, canals can be observed which retain water, in the event of an overabundance of rain, for a certain number of days, in order to be able to water the crop in the event of delayed rain. This system protects crops from flooding in low pressure areas such as Houeli-Gaba towards Massè. In total, seven (07) sites are developed (16.27\%) based on the type of development.

\subsection{4- Hydro-agricultural development by watering plants}

This type of arrangement is practiced on the plateau and consists of taking water from the watering cans to water the plants manually, as shown in photo 4 .

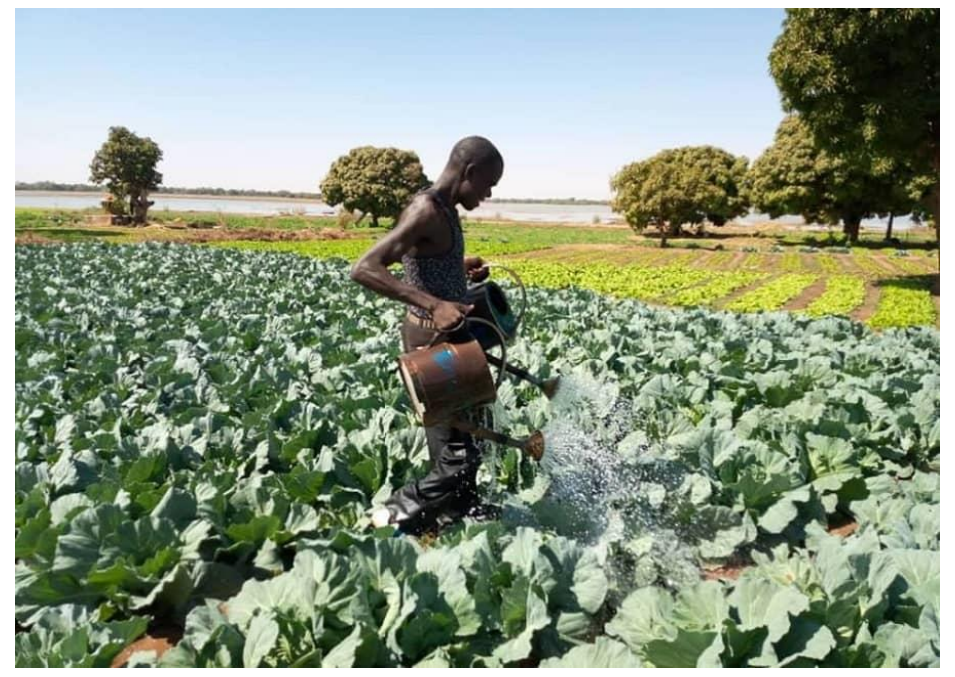

Photo 4: Crop irrigation in Ita-Bolarinwa (Ikpinlè) 
Shooting: Zannou, September 2020

Photo 4 shows an active producer for off-season and seasonal production, especially market gardening. This arrangement is mainly used by producers who do not have the means to carry out modern arrangements; only 2 developed sites have adopted this technique, ie $4.65 \%$.

\subsection{5- Hydro-agricultural development by ridges and ridges}

Given the difficulties associated with water control, the ridge and hill system is used to channel and evacuate excess water during rainy periods. It consists of raising the soil to sow crops. It is an agricultural practice that avoids the contact of speculation with runoff water and facilitates the aeration of the soil and the trouble-free burying of roots, especially tubers, in the soil. Ridging takes place at the start of the rainy season because it retains more water and allows the combination of crops. This practice, which is not new, is the second type of development in the municipality $(23.26 \%)$.

\section{2- Spatialization of hydro-agricultural developments}

Hydro-agricultural developments are unevenly distributed in the municipality of Adja-Ouèrè. It should be noted that on most sites, the combination of facilities is visible. The most notable is that of the development by mound and ridge with traditional sprinkling. Figure 3 shows the distribution of hydro-agricultural development sites in the Municipality.

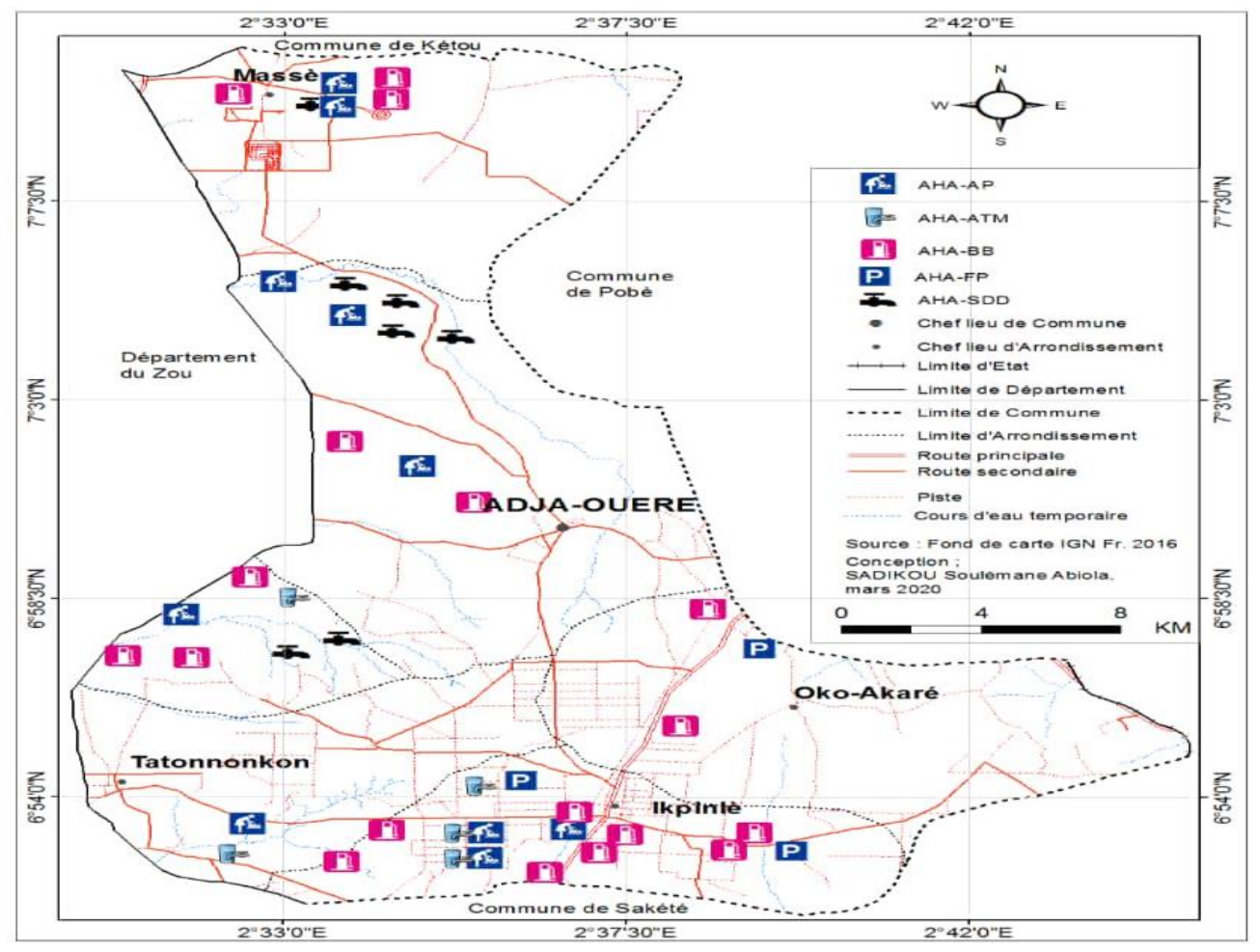

Figure 3: Spatial distribution of types of hydro-agricultural development in the municipality 
AHA-FP: Hydro-Agricultural Development by Pumping or Drilling; AHA-AP: HydroAgricultural Development by Watering Plants; AHA-SDD: Hydro-Agricultural Development by System of Dikes and Bunds; AHA-BB: Hydro-Agricultural Development by Billonnage and Raising; AHA-ATM: Hydro-Agricultural Development by Traditional and Modern Sprinkling

On reading Figure 3, there are 43 hydro-agricultural development sites distributed in the 6 districts of the municipality of Adja-Ouèrè, organized into 05 categories which are: the development by system of dikes and bunds (16,27 \%), developments by drilling (2.33\%), developments by sprinkling (53.49\%), by ridges and ridges (23.26) and developments by sprinkling $(4.65 \%)$. The Ikpinlè district is the one where the developments are the most important with a total of 18 developed sites, i.e. $41.86 \%$ and the Oko-Akare District is the one where the developments are almost non-existent (only 3 sites or 6.97\%).

In the research sector, crops vary according to the types of hydro-agricultural development. Market gardening covers around $40 \%$ of the facilities and is mainly carried out in the pumping and watering system. Cereal crops represent $32 \%$ of hydro-agricultural developments and dominate in the ridge and hill management system and also dykes and bunds (especially maize), while rice is mainly grown in the sprinkler schemes. Tubers only represent $14.29 \%$ of irrigation schemes and are used in the ridges and mounds system. As for legumes and other fruit trees, they represent $13.71 \%$ of the overall development.

\section{3- Socioeconomic impacts of hydro-agricultural developments}

\subsection{1- Social impact of hydro-agricultural development: job creation}

The implementation of irrigation schemes contributes to the creation of jobs and therefore to the reduction of unemployment in the municipality of Adja-Ouèrè. Indeed, labor is one of the determining factors of agricultural production. There are different forms of labor in hydroagricultural development sites: collective labor, wage labor (Table I).

Table I: Different types of labor encountered in the sites

\begin{tabular}{|l|l|c|c|c|}
\hline Type of layout & \multicolumn{1}{|c|}{ Roles } & Types of labor & $\begin{array}{l}\text { Number } \\
\text { persons }\end{array}$ & $\begin{array}{c}\text { Cout } \\
\text { (FCFA) }\end{array}$ \\
\hline $\begin{array}{l}\text { Hydro-agricultural } \\
\text { development by planking, } \\
\text { drilling }\end{array}$ & $\begin{array}{l}\text { Clearing, } \\
\text { transplanting, } \\
\text { maintenance }\end{array}$ & $\begin{array}{l}\text { Monthly } \\
\text { salary }\end{array}$ & 35000 \\
\hline $\begin{array}{l}\text { Hydro-agricultural } \\
\text { development by } \\
\text { modern and } \\
\text { traditional sprinkling }\end{array}$ & $\begin{array}{l}\text { Clearing, } \\
\text { transplanting, } \\
\text { maintenance }\end{array}$ & $\begin{array}{l}\text { Monthly } \\
\text { salary }\end{array}$ & 3000 \\
\hline Arrangement hydro- & Land clearing, & Collective & 12 & Free \\
\hline
\end{tabular}


International Journal of Agriculture, Environment and Bioresearch

Vol. 06, No. 05; 2021

ISSN: $2456-8643$

\begin{tabular}{|c|c|c|c|c|}
\hline $\begin{array}{l}\text { agricultural by } \\
\text { system of dikes and } \\
\text { bunds }\end{array}$ & $\begin{array}{l}\text { Constitution of bunds, } \\
\text { Transplanting }\end{array}$ & Daily salary & 7 & 2000 \\
\hline \multirow{3}{*}{$\begin{array}{l}\text { Hydro-agricultural } \\
\text { development of } \\
\text { ridges and mounds }\end{array}$} & \multirow{3}{*}{$\begin{array}{l}\text { Clearing, creation of } \\
\text { ridges and mounds, } \\
\text { transplanting, } \\
\text { maintenance }\end{array}$} & Collective & 12 & Gratuit \\
\hline & & Annual salary & 2 & 420000 \\
\hline & & Daily salary & 4 & 2000 \\
\hline $\begin{array}{l}\text { Irrigation irrigation } \\
\text { system }\end{array}$ & $\begin{array}{l}\text { Clearing, watering, } \\
\text { transplanting, } \\
\text { maintenance }\end{array}$ & Monthly salary & 5 & 35000 \\
\hline Total & - & - & 48 & \\
\hline
\end{tabular}

Source: Survey results, April-September 2020

According to the information in Table I, the establishment of the 43 developed sites in the municipality of Adja-Ouèrè has already directly generated 48 jobs, $50 \%$ of which are paid. But in traditional systems without planning, the workforce is exclusively family-based, and therefore does not create new jobs. The financial burden related to the workforce of the 43 sites is estimated at 10,920,000 FCFA without counting the expenses related to the collective workforce.

\subsubsection{Economic impact of hydro-agricultural developments}

The economic benefits vary from one type of development to another, as do the expenses necessary to carry them out. Table II shows the profitability of each type of hydro-agricultural development in the municipality of Adja-Ouèrè.

Table II: Profitability of hydro-agricultural developments

\begin{tabular}{|l|l|l|}
\hline Types of hydro-agricultural development & $\begin{array}{l}\text { Construction / } \\
\text { maintenance } \\
\text { cost (one } \\
\text { hectare plot) }\end{array}$ & $\begin{array}{l}\text { Annual } \\
\text { profit } \\
\text { (FCFA) }\end{array}$ \\
\hline hydro-agricultural development by drilling & 3.811 .000 & 2.202 .000 \\
\hline hydro-agricultural development by modern sprinkling & 3.811 .000 & 850.000 \\
\hline
\end{tabular}


Vol. 06, No. 05; 2021

ISSN: $2456-8643$

\begin{tabular}{|l|l|l|}
\hline Hydro-agricultural development by traditional sprinkling & 150.000 & 705.000 \\
\hline Development by system of dikes and bunds & 432.000 & 855.000 \\
\hline Hydro-agricultural development by mound and ridge & 255.000 & 435.000 \\
\hline Hydro-agricultural development by sprinkling & 325000 & 552.000 \\
\hline
\end{tabular}

Source: Survey results, April-September 2020

According to the information in Table II, the most profitable types of development are those which require more financial means for their realization. These are developments by drilling and modern sprinkling, the construction costs of which are around 3,811,000 FCFA but with profits respectively in the order of 2,202,000 FCFA and 850,000 FCFA. The other developments are no less profitable with the annual profits sometimes exceeding twice the investment.

\section{4- Constraints linked to hydro-agricultural developments}

Hydro-agricultural developments provide significant economic benefits to the households concerned. However, despite the significant role of income or profits made, these hydroagricultural developments are faced with various constraints as shown in Figure 4.

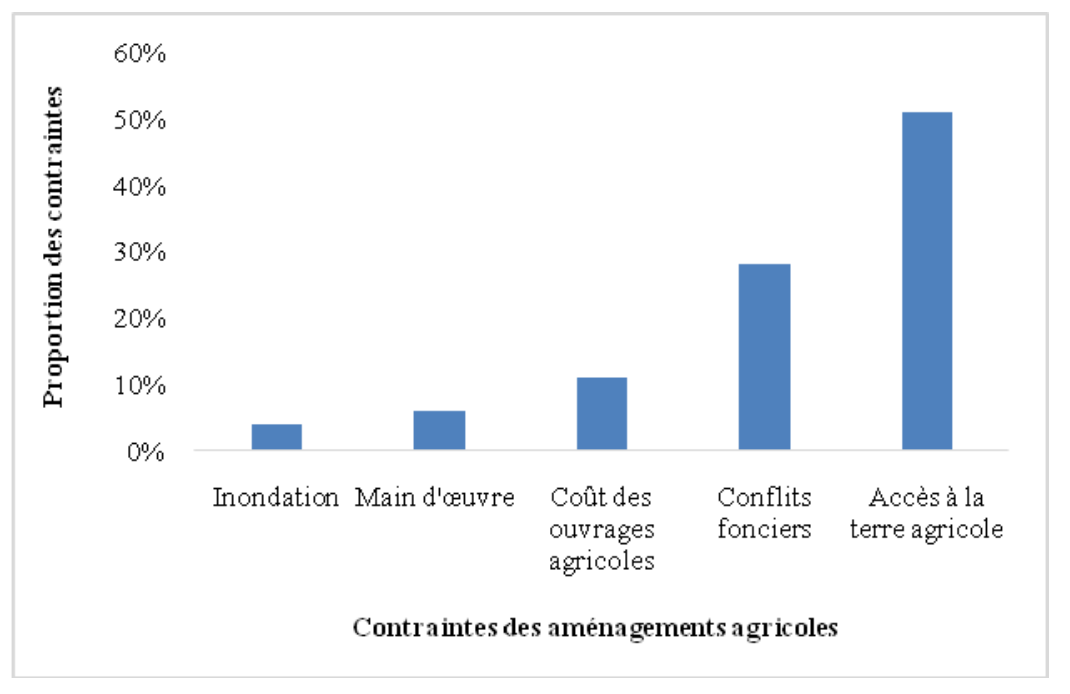

Figure 4: Different constraints of hydro-agricultural developments

Source: Field surveys, April to September 2020

On reading Figure 4, access to land is the main difficulty (around 50\%) encountered by agricultural households in the municipality and which generates land disputes (30\%), which makes the implementation of facilities more precarious. hydro-agricultural and their profitability.

Indeed, land conflicts and difficulties in accessing agricultural land are the constraints that are strongly observed in the municipality. The price of agricultural land, which was 150,000 FCFA 
Vol. 06, No. 05; 2021

ISSN: $2456-8643$

per hectare in 2005, rose to 500,000 FCFA or even 700,000 FCFA in 2020, constituting both an economic, political and social issue. The other constraint is the high cost of agricultural works, which exceeds the financial capacity of producers. For $45 \%$ of respondents, it takes an average of 2,500,000 FCFA to engage in agricultural development. Thus, many households opt for developments by ridges or dikes and bunds and take advantage of rain or surface water. The scarcity of labor and frequent flooding discourage many farm households from embarking on irrigation schemes.

\section{DISCUSSION}

Agriculture is the basis of the local economy in the municipality of Adja-Ouèrè. Thus, efforts are being made to improve production techniques, notably with the realization of hydro-agricultural developments. There are five (5) types of development, but the most used are sprinkler systems (approximately $70 \%$ of farmers surveyed). These results are similar to those obtained by J.P. Boumboundi (1990, p.44) who had shown that "the development of the perimeter of the Tansobentenga plain in the province of Kouritenga is mainly done by dikes and by watering plants". However, this research brings a nuance to the results of this same author concerning the cultures practiced on the developed sites. In fact, fish farming activities do not take place in the municipality of Adja-Ouèrè as he noticed in the province of Kouritenga. Rather, we find market gardening and cereal production (especially rice and corn).

Speaking of the combination of techniques, the most noticed at the end of this research is that of the development by mounds and ridges with traditional sprinkling. This is not the case with the results obtained by CTB $(2017$, p.2) which said that "if the water is far away, it must be pumped, irrigated on dikes and bunds. Thus, developments of this kind have been made in Senegal to sustainably improve agricultural productivity in the groundnut basin. The types of hydroagricultural development that have been put in place in this basin are drilling and irrigation ".

The establishment of hydro-agricultural facilities offers many advantages, including job creation, agricultural production in all seasons and relative control of water. This control of flooded water for agricultural purposes was also reported by MAA (2014, p.23) in France in their project to take into account agricultural activity and natural spaces within the framework of management. flood risk.

In terms of work organization, this research revealed that the operators of the municipality of Adja-Ouèrè operate the sites individually and therefore, there are no cooperatives or farmer associations. This does not allow them to take advantage of the many advantages shown by GBAD (1992, p.6) in Niger in hydro-agricultural perimeters where the State has organized farmers into cooperatives or the benefits noted by CH Sossou (2015, p.24) which has proven that farmers' membership in an association facilitates access to agricultural credit in Benin. To this are added many other constraints determined in this research such as the lack of manpower, the weak financial capacity of producers and the weak political involvement. These results confirm those obtained by the FAO (2000, p 10) which took stock of hydro-agricultural development in Africa. 
Vol. 06, No. 05; 2021

ISSN: $2456-8643$

\section{CONCLUSION}

This research devoted to hydro-agricultural developments in Adja-Ouèrè was an opportunity to assess the socio-economic impacts of these developments in the town. The results obtained show that the municipality has 43 developed sites divided into 5 main types of hydro-agricultural development. The most common type of development is traditional sprinkling with 23 sites developed or $53.48 \%$ followed by development by mounds and ridges (10 sites or 23.25\%). Various crops are produced on the developed sites but the dominant crops are vegetable and cereal crops. The operation of these facilities provides social benefits such as job creation (48 out of the 43 sites) and generates profits ranging from 435,000 FCFA to 2,202,000 FCFA per year depending on the type of hydro-agricultural development implemented. in place. However, several constraints hamper the realization and profitability of these hydro-agricultural developments. These are mainly the high cost of hydro-agricultural development works, floods, difficult access to agricultural land, land disputes, lack of labor, weak involvement of local authorities and lack of supervision of producers. It is therefore desirable that the marie, the supervisory structures, the NGOs support these initiatives for the promotion of integrated dikepond and hydro-agricultural systems which combine agriculture, livestock and fish farming for more profitability in their activity.

\section{REFERENCES}

WARDA, 2005. Successfully diversifying the livelihoods of rural and urban populations in subSaharan Africa, In annual report 2003-2004: Towards new horizons, 72 p.

AGBAZAHOU Sévérin, 2013. Socio-economic and environmental impacts of irrigated lowland rice cultivation: case of Koussin-lélé in the commune of Covè, dissertation by DEA, EDP / FLASH / UAC, Benin, 103 p.

AGBODJEGBE Jean-Gaston, 2008. Economic, health and environmental impacts of the development of the Aizè lowlands, commune of Ouinhi Department of Zou, agricultural engineering thesis in DAGE / FSA, UAC, Benin, $152 \mathrm{p}$.

BOUMBOUNDI Jean-Paul, 1990. Study of a hydro-agricultural development and its socioeconomic implications in rural areas: the Tansobentenga plain in the province of Kouritenga, master's thesis, National Institute of Human and Social Sciences Department of Geography of the University of Ouagadougou, $97 \mathrm{p}$.

CTB, 2017. Towards an inclusive management of hydro-agricultural structures, Senegal Agriculture Experiences, Capitalization document, $\mathrm{N}^{\circ} 2,16 \mathrm{p}$.

Direction Générale de l'Eau (DGEau), 2008. Hydrographic Atlas of Benin An Information System on Hydrography, Support Program for the Development of the Water and Sanitation Sector, $22 \mathrm{p}$.

EHOULO Yvette Folakè, 2008. Development of lowlands and agricultural production in the district of Houèdo / municipality of Abomey-Calavi, Master's thesis in geography, FLASH / $\mathrm{UAC}, 87 \mathrm{p}$. 
FAO and Songhaï, 2010. Promotion of agricultural entrepreneurship for the socio-economic transformation of rural areas in Benin, Joint project document, $78 \mathrm{p}$.

FAO, 2000. Hydro-agricultural developments in Africa: current situation and prospects, $10 \mathrm{p}$.

African Development Bank Group (GBAD) 1992. Kourani Baria Hydro-Agricultural Development Project, Project Performance Appraisal Report (REPP), 93p.

HOUINTCHEKPO Flavien, 2019. Environmental and socio-economic impacts of rice cultivation in the district of Koudo (Municipality of Lokossa). Master's thesis in geography, FLASH / UAC, Benin, 79 p.

HOUNKPETIN Caroline, 2003. Contribution to the development of the Okéita lowlands in the commune of Pobè, (Plateau Department), Agricultural engineer thesis, DGAT / FLASH, UAC, Benin, $134 \mathrm{p}$.

INSAE, 2013. Population size of villages and city districts in Benin, 4th General Population and Housing Census, Benin 85 p.

LANOKOU Mathieu, OGOUWALE Euloge and AFOUDA Fulgence, 2013. Extreme rainfall and constraints to agricultural development on the black soils of South Benin (West Africa). Cotonou-Bénin, Act of the XXVIth conference of the International Association of Climatology, pp: 324-329.

Weather Benin, 2019. Climate database of South Benin, Excel file, Cotonou, ASECNA, 201p.

Ministry of Agriculture and Food (MAA), 2014. Taking account of agricultural activity and natural spaces within the framework of flood risk management, guide intended for local actors: agricultural activity section - version 2, $126 \mathrm{p}$.

PNIA / ECOWAP / CAADP, 2008. As part of the formulation of the National Agricultural Investment Program, Summary produced under the aegis of the MAEP, $36 \mathrm{p}$.

SOSSOU Comlan Hervé, 2015. The financing of agriculture in Benin: management strategies and adaptation of agricultural holdings, Original dissertation presented with a view to obtaining the degree of doctor in agronomic sciences and biological engineering, University of Liège, Belgium, $54 \mathrm{p}$. 